\title{
Communication between mothers and children about environmental issues (a study about the role of mothers to educate their children on keeping a clean environment)
}

\author{
Chandra Kirana ${ }^{1, *}$ \\ ${ }^{1}$ Department of Communication Science, FISIP Universitas Indonesia, Indonesia
}

\begin{abstract}
For the last two decade, many studies about environmental issues show that interpersonal communication plays an important role. Interpersonal communication is very useful and strategic to involve people to take part on this issue, particularly on how people deal with waste management (how to keep a clean environment). By using interpersonal communication approach at the micro level, this can lead us to identify and understand more about the whole elements of communication process (communicator, receiver, message, medium (channel), and effect) when we need to deal with the environmental issues. Based on what I observed about the communicator's role in this paper, I argue that mothers have significant role to educate their children to keep a clean environment. This paper aims to explain the role of mothers on how they educate the children to keep a clean environment. This study use in-depth interview to 5 mothers who have children in Jakarta, Bogor, Depok. The data will be analyzed by thematic analysis. The findings indicate, to educate the children about keeping a clean environment, mothers needs to communicate interpersonally by using some examples, personal experiences, personal values, and certain media to discuss about this issue to their children.
\end{abstract}

\section{Introduction}

In the past few decades, the issue of the environment has become one of the important global issues; besides the issue of poverty and hunger eradication, education, health, gender empowerment, etc. Those things can be found in the Millennium Development Goals, set by the United Nations (UN) in 2000-2015 (1). Furthermore, the organization stated that environmental issues become an important priority in some of indicators in SDGs Sustainable Development Goals (2). This paper will contribute to SDGs especially in some aspects such as sustainability in education [SDG \#4], women and sustainability [SDG \#5 and \#17].

Generally, the issue of the environment is in a broad spectrum, ranging from maintaining environmental cleanliness (including land, river, sea and air), clean water procurement, natural resources saving (e.g. water and energy [electricity]), global warming, climate

\footnotetext{
${ }^{*}$ Corresponding author: chandra.kirana@ui.ac.id
} 
change, pollution, and so on. In short, environmental issues are important to consider because the physical environment is the habitat for humans and other living things that are depending each other, over a long period of time.

In the last two decades, a number of studies have shown that communication studies play an important role in a series of studies on the environment; especially studies of environmental communication. This study provides space to perform the education function (providing knowledge), persuasion, collaboration and advocacy with other individuals/organizations to create a healthy or proper environment to be inhabited by other individuals or living things. Practically, in the perspective of the communication process, the issue of environmental management will involve communication elements such as communicators (senders/ recipients), messages or content of communication (verbal and nonverbal symbols, meaning, etc), media used, and communication effects (3) (4) (5) (6). This paper starts from a micro level in observing environmental issues - i.e., how individuals maintain and create a clean environment (especially in waste management). Concerning to that, this paper aims to explain the role of mother - as communicator (educator who provide education to children) in maintaining or keeping the clean environment.

The selection of this topic is based on the author's observation of a number of cases in everyday life, which shows that the mother is a key figure who plays an important role for children to maintain good behavior in every daily activities, including how to maintain the environmental cleanliness. Therefore, the researcher argues that mother has a strategic role to form children's behavior in protecting the environment - especially how individuals manage waste at their social context. This could be done if the interpersonal communication between mothers and children takes place (7). DeVito stated, interpersonal communication is a process that takes place between or among connected persons or those involved in a close relationship (8).

Culturally, the role of care and education of children is inherent in the mother in the process of setting values in the family. Although the process of setting values also involves other in the family, but in most situations, the role of the mother is dominant in instilling values for the child. In this context, the intended values are values related to things that are considered important to be attached to daily life. Those include social values (in relation to social interaction), cultural values (related to the rules/cultural norms that exist in the family) and personal values or individual values (values inherent in an individual which are the result of the interaction of social values as well as cultural values and personal values that exist).

The study will explain the following research questions, i.e.:

1. What is the role of mother in addressing the environmental issues in everyday life?

2. How does mother know about environmental issues? What media that she use to get the knowledge?

3. How does mother socialize knowledge about environmental issues?

4. What activities that a mother does to give knowledge about maintaining environmental cleanliness to her children?

\section{Literature review}

In 2001, Hudson (9) wrote that as we enter a new century, environmental educators must come up with new knowledge and techniques that address the demands of social and technological landscape, while ensuring that environmental education stays relevant to the community. These challenges to environmental education required that we must reexamine the way we communicate environmental information to the public. Nowadays, it is important to focus on communication approach to understand and deliver the messages about environmental issues. In line with this, the needs of collaborative research between environmental studies and communication science is a must (10). This study explain the role 
of mothers in communicating the environmental issues interpersonally to her children, so that they could have sufficient knowledge and practice to keep a clean environment. Some studies about behavioral change issues shows that the interpersonal communication in family/individual level play a strategic way to change people's behavior to a better situation (11). In addition, Meeusen stated that the role of family considered to be powerful in transmitting knowledge, values and practice to the whole family members (12).

\section{Research methods}

This study is a descriptive study that uses a qualitative approach (13) (14). In order to collect data, I use in-depth interviews (with interview guidelines) on a number of informants (5 mothers). The selection of informants was done purposively to get the appropriate informants. The data obtained in this interview were analyzed thematically.

In determining the informants, there are a number of criteria in this study, namely, 1) mothers who have elementary school children (assuming that the elementary school age child is able to communicate verbally and can understand the message from the mother - especially those related to messages about how to maintain environmental cleanliness), 2) communicating ways to maintain environmental cleanliness to children, 3) domiciled in Jabodetabek (the area consideration is important because researcher must conduct in-depth interviews). In recruiting informants, researchers conducted snowballing technique. Prior to the interview, the place of the interview is determined based on mutual agreement. Some informants were interviewed at their office because the interview was carried out at office hour. To date, there are five informants who have been interviewed.

This research use two goodness criteria applicable to qualitative research: credibility, and comfortability (15). The weakness of this research is that, this study only focus on urban context. Additionally, researchers did not conduct an observational method.

\section{Findings}

It is found that there are some factors that shaped human behavior in keeping a clean environment. Those factors are, 1) role of mothers, 2) social context, and 3) child's capacity in coping this issues as it is shown below:

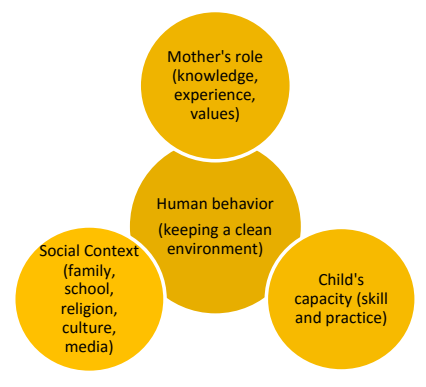

Fig. 1. Factors that shape human behavior on keeping a clean environment.

Based on the interviews conducted, the researcher found some results as follows:

1. Environmental issues are not a major issue in socialization but this is considered important.

Mrs. A: I habitually don't talk about environments, but at least she knows to throw garbage in its place. 
Mrs. B: For me, the important thing is to teach children to save electricity.

Mrs. D: (environment issues) is really important, maybe because of information from the media that I often read. Such as Kompas (newspaper), Tempo (newspaper), moreover in the WA group (WAG).

Mrs. E: At first I started with (ideas) if we are clean, it's good for health. Well, I always remind children to take a shower every day. Then, I remind them to use water adequately. And then, if you open the soap wrap, throw it in the trash bin.

2. Religion is an important means of practicing how to protect the environment.

Mrs. C: My religion is teaching the way to maintain harmony, in harmony with other people, with animals, with plants and trees, the environment or nature around and with the Creator. So, for me the religion is important for teaching ... to apply ways in protecting the environment around.

Mrs. A: My religion teaches that cleanliness is part of faith ...

Mrs. E: Religion is a factor that helps me to maintain cleanliness. But there are other factors, for example in my office I meet with environmental activists who often remind us how to manage waste, how to choose environmental-friendly products. Then I also watched TV with the issue of "earth hour". Various ways.. So, religion is just one thing.

3. Environmental issues or messages are practiced simply every day, such as throwing garbage in its place, separating waste types, using products that can be used many times, using recycled products, and saving water and electricity.

Mrs. D: When I was kid, I was taught by my parents to clean up. I want my children also to be like that... at least they clean up toys, throw out the trash to its place, then if the toys are not used anymore, it can be donated to someone else.

Mrs. C: I have seen in TV and my office that the garbage should be separated. At least in my house, I started to separate the plastic drink bottles that were bought on the road... If I remember... I just knew that the school taught my child to separate garbage, such as plastic, newspaper, bottles. Then, the parents are also encouraged by the school to bring such garbage to school since there is already a shelter. I think it's a good idea to have (garbage) shelter like this.

Mrs. A: I've often been upset when my child forgets to turn off the electricity (lights) and the faucet in the bathroom. It is expensive. Maybe this is not about the environment, but it is a shock because it still has to be paid. Well, I also like to turn on TV if the house is empty. Usually, if I remember that there's no one watching TV, I turn it off directly.

Mrs. B: I usually teach my children to bring lunch from home, anything available at home. If I have time, I cook. If I don't have time, I just buy (the meals) at a shop nearby. The drinking bottle is brought from home in order to save money, than buy (the water) every day. But, my kids sometimes forget to take the lunchbox and drinking bottle home. Mrs. E: I remember, when I was a kid, at the toll roadside, I read an announcement "Do not litter", I still remember it until now. I was scared, if there is a police officer who angry with me because of littering. Then another most memorable experience was, when I was little I lived with my grandmother. She loved cleanness. Also, I used to accompany her to take care of her goats. When she helped the goats give birth, I saw my grandmother was really careful until all the goatlings were born. Then, if all the goatlings were born and their mother couldn't breastfeed them, my grandmother made milk to feed the goatlings. My grandmother also has a fish pond. If the pond is drained, the fish can be eaten, shared with neighbors, or sold, etc, and the goats can be sold for sacrifice at the Ied Adha, or such other events. Well, for me the environmental issue also includes something like those. Maintain harmony with animals, and the surrounding environment. 
4. The media used to increase environmental knowledge are social media, TV (TV shows, documentary films, news, etc.), WA groups, articles in newspapers (online), and direct interaction (co-workers, rules at the office, etc.)

Mrs. A: I usually watch shows or news about that (environmental issue) on TV.

Mrs. B: from magazines, women's talk at the office, Facebook, rules at the office.We have been told that the lights must be off if they are not used.

Mrs. C: I have read in the newspaper, I (forget since) I rarely read the newspaper, that mentioned the garbage had to be separated.

Mrs. D: hmmm, my child told me, my husband asked us to clean up, things like that. My child was taught from his school to separate garbage, put it to the right place, then in his school there were also planting activities (gardening). Pretty cool, I can buy cheap vegetables from his school.

Mrs. E: I got the information from various resources. I don't remember the detail; but there are some environmental activist at my office who often ask and remind us to separate garbage, to reduce plastic, use mass transportation, bring our own drinking bottles. There is a program from NatGeo about protecting the environment. I was also told by my child because he likes reading books and watching NatGeo about "earth hour"

5. Children or other family members can maintain environmental cleanliness because their parents (father or mother and even grandmother) provide examples directly to them (being role-models).

Mrs. D: As far as I remember, when I was a child, my mother and my father taught me to throw the garbage in the trash. If I can't find a trash bin, I have to hold it, keep it until I arrive at home, and then throw it into the trash bin. I remember it until now. So, I teach my child like that. To keep the garbage first, in the bag or else, the important thing is not to litter.

Mrs. E: My parents did not teach me about environment issue. What I remember from them, I have to go to school until I finish. Regarding cleanliness, the environmental issue was actually I got from my grandmother.

6. School and religious institutions are considered important in habituating people to maintain environmental cleanliness.

Mrs. D: At my place of worship, (Mrs. D is Hindu), keeping the temple clean is the responsibility of the residents. So the habit of taking care of cleanliness is also I got from there, besides I got it from my parents.

Mrs. C: I am usually looking for a public school. When I was looking for a school, I chose a school with good quality; such as the quality of teachers, curriculum, graduates, the building. Environmental hygiene matters are not a priority. But I am lucky that in my child's school the waste separation program is $O K$.

Mrs. A: I used to go to a Catholic school, which the cleanliness issue was important. I remember that almost all furnitures or tools at school were old, old-fashioned, but they were cleaned up, so they were well-maintained. Garbage also doesn't look dirty, because it was cleared by the officers, so it didn't mess. Not so dirty.

Mrs. E: Yes, the school is important... I have some considerations about the choice of school, starting from the curriculum, facilities, the capacity of the teachers, distance, etc. However, don't forget that environmental matters are also shaped by various factors, such as at-home socialization, workplace rules, media roles are also important ... 
7. Environmental issues are the responsibility of parents

Mrs. C: (that is) the parents' responsibility. Yes, the same thing with the school, so I can guard together. At least the school can also help parents - to remind that it is important to get rid of garbage or to clean their things ...

Mrs. D: it should be (the responsibility) of the family, the extended family... not only my nuclear family.

Mrs. A: actually, I don't really think about this. However, if my child becomes dirty, he can't throw trash or other thing, it will bother too ... at least the mother or father is the one who teaches him. But, how if we forget about that ... hahhaha ...

8. Activities in the form of concrete examples are good ways for children to protect the environment

Mrs. B: I am more accustomed to giving a direct example, yes ... I can see that she (the child) is going to throw garbage in a right place if her father and mother give a direct example

Mrs. C: I prefer to take my kids to do some projects together based on some information from their school, our religious practice, or from my relatives. Something like planting vegetables, do walk together, etc.

Mrs. D: since my parents became the example for me, I also do that with my child so she learned from me and from her grandparents.

Mrs. A: I'm happy if there is a TV program that can give a direct example. For example, when there are flooded areas seen on TV. I can tell him, "See, there are areas that are flooded, that's because of the garbage"...

Mrs. E: Sometimes I like to take them to a nice and clean place for a camping. Later I can say to them that if people keep the area clean, the place will be comfortable, right ...

The following table shown below will summarize those data from all of the informants for some key concepts.

Table 1. Results of data analysis from informants about environmental issues.

\begin{tabular}{|c|l|l|l|l|}
\hline Concept & Definition of & Knowledge about & Mother's role in & Media of \\
\hline Informant & \multicolumn{4}{|c|}{ Environmental issues } \\
\hline A & $\begin{array}{l}\text { Save energy (water } \\
\text { and electricity }\end{array}$ & TV & $\begin{array}{l}\text { Educate by showing } \\
\text { TV Program }\end{array}$ & TV \\
\hline B & $\begin{array}{l}\text { Saving in bring lunch } \\
\text { and drink from home }\end{array}$ & $\begin{array}{l}\text { Role model from } \\
\text { parents }\end{array}$ & $\begin{array}{l}\text { Educate by giving } \\
\text { direct example }\end{array}$ & $\begin{array}{l}\text { Magazine, } \\
\text { Facebook, TV, } \\
\text { direct interaction }\end{array}$ \\
\hline C & $\begin{array}{l}\text { Garbage separation } \\
\text { (plastic, bottle, etc) }\end{array}$ & $\begin{array}{l}\text { Media, family, } \\
\text { religion }\end{array}$ & $\begin{array}{l}\text { Educate by doing } \\
\text { activities together }\end{array}$ & Newspaper \\
\hline D & $\begin{array}{l}\text { Clean up/Tidy up, } \\
\text { use recycled product. }\end{array}$ & $\begin{array}{l}\text { Role model from } \\
\text { parents, family \& } \\
\text { child's school }\end{array}$ & $\begin{array}{l}\text { Educate by giving } \\
\text { direct example }\end{array}$ & $\begin{array}{l}\text { TV, Kompas, } \\
\text { Tempo }\end{array}$ \\
\hline E & $\begin{array}{l}\text { Do not litter, } \\
\text { cleanliness and } \\
\text { maintaining harmony }\end{array}$ & $\begin{array}{l}\text { Role model from } \\
\text { grandma }\end{array}$ & $\begin{array}{l}\text { Educate by doing } \\
\text { camping together }\end{array}$ & $\begin{array}{l}\text { WAG, film } \\
\text { (NatGeo), direct } \\
\text { interaction }\end{array}$ \\
\hline
\end{tabular}

\section{Conclusion and recommendation}

\subsection{Conclusion}

Based on the field data, related to the research objectives, this can be concluded that: 
- Environmental issue is not primary issue, but it is still considered important for mothers in carrying out their role to conduct socialization and education in environmental issues

- In obtaining knowledge about environmental issues, mothers use various media such as social media, the internet, online media, TV, magazines and newspapers and through direct interaction with women/neighbors and people in the workplace.

- To provide knowledge and socialization to children, the mothers teach by giving direct examples.

- To explain specific activities that can provide knowledge for children about how to maintain environmental cleanliness is to involve children to take a walk/do camping to a clean place, so that children can feel the direct benefit of maintaining environmental cleanliness activities, watch TV that broadcast environment issues, invite the children to discuss about the environmental issues.

\subsection{Recommendation}

This research is done in urban setting. It will be better if the research involves both urban and rural contexts. Ideally, the research should conduct the mixed-methods which involve collecting data quantitatively and qualitatively (observation technique) to obtain rich data. For the next research, it is important to involve the father to be interviewed.

\section{References}

1. UNDP, http://www.who.int/topics/millennium_development_goals/about/en/

2. UNDP, https://sustainabledevelopment.un.org/sdgs

3. R.R. Jurin, D. Roush, J. Danter, Environmental Communication (Springer, Dordrecht, 2010)

4. A. Hansen, Environment, Media and Communication (Routledge, London, 2010)

5. B.D. Ruben, L.P. Stewart, Communication and Human Behavior (Allyn \&Bacon, 2006)

6. R. West, L.H. Turner, Introducing Communication Theory: Analysis and Application (McGraw-Hill, New York, 2010)

7. C.A. Klöckner, The Psychology of Pro-Environmental Communication (Palgrave Macmillan, London, 2015)

8. J.A. De Vito, The Interpersonal Communication Book. Fifteenth Edition (Pearson Education, Inc., Boston, 2019)

9. S.J. Hudson, Bio Science 51, 4 (2010)

10. L. Davis, et al., Environmental Communication 12, 4, $431-437$ (2018)

11. M.E. Burns, J.C. Pearson, Communication Studies 62, 2, 171-185 (2014)

12. C. Meeusen, The Journal of Environmental Education 45, 2, 77-90 (2014)

13. J. Creswell, Research Design: Quantitative, Qualitative, and Mixed Methods Approaches (Sage Publications, Inc., Thousand Oaks, 2014)

14. W.L. Neumann, Social Research Methods: Qualitative and Quantitative Approaches 6th Edition (Pearson, Boston, 2006)

15. M.Q. Patton, Qualitative evaluation and research methods (3rd ed) (Sage Publications, Inc., Thousand Oaks, 2002) 